\title{
ORIENTACJA TEMPORALNA A POSTAWA WOBEC ŚMIERCI
}

\author{
Wprowadzenie
}

Czas jest jednym z podstawowych typów doświadczeń ludzkich, człowiek bowiem w nim trwa i tworzy siebie. Nie mogąc ująć czasu całościowo, rozczłonkowuje go na: przeszłość, teraźniejszość i przyszłość. Dzięki temu szereg zdarzeń, z jakimi się spotyka, może opisywać używając określeń „,wcześniej”, „teraz”, „,później”.

W egzystencjalnym ujęciu czasu zwraca się uwagę na jego szczególne powiązania z identycznością własnego ,ja” ${ }^{1}$. Swiadomość czasowości egzystencji jest czynnikiem koordynującym wszelkie fundamentalne doświadczenia ludzkie, gdyż ,przeżywanie zarówno własnej identyczności jak i sensu życia jest nieoddzielnie związane z subiektywnym doświadczeniem czasu" ${ }^{2}$. Wynika $\mathrm{z}$ tego, że zaburzenie czasowej perspektywy prowadzić może do różnego rodzaju kryzysów i stąd psychopatologiczne stany opisuje się jako zaburzenia percepcji siebie i czasu, np. Minkowski ${ }^{3}$ uważa, że w schizofrenii centralnym problemem jest utrata żywej synchroniczności, bowiem dynamiczna siła życia (elan vital) nie „współbrzmi” z procesami świata zewnętrznego. W psychotycznej depresji zaś elan vital słabnie lub zanika a psychologicznym skutkiem tego jest przeświadczenie jakoby przyszłość była zamknięta lub nieobecna.

Psychologowie o orientacji humanistyczno-egzystencjalnej zgodni są w akcentowaniu niezwykłej wprost roli czasu w strukturyzowaniu osobowości, z tym, że podkreślają w sposób szczególny rolę przyszłości. Jeden z nich pisał: „Osobowość można zrozumieć jedynie wówczas, kiedy widzi się ją jako zdążającą ku przyszłości ... osoba ciągle się staje, ciągle odsłania się w przyszłości" " . Osoba, która pragnie żyć autentycznie, a zatem także twórczo, musi mieć perspektywę przyszłości, by wypełnić ją swą inwencją. 1975.

1 Por. E. H. Erikson, Life history and the historical moment, N. York

${ }^{2} \mathrm{H} . \quad \mathrm{R}$ appaport, K. Enrich, A. Wilson, Ego identity and temporality: psychoanalytic and existential perspectives, „Journal of Humanistic Psychology" 22(1982), 54 .

${ }^{3}$ Por. E. Minkowski, Findings in a case of schizophrenia depression, [w:] R. May, E. Angel, H. F. Ellenberger (eds.), Existence, N. York 1958, $132-133$.

${ }^{4}$ R. M a y, Contributions of extential psychotherapy, [w:] Existence, op. c., 69 ; por. C. R. Rogers, On becoming a person, Boston 1961. 
Ze względu na charakter prezentowanego artykułu z bogatej problematyki czasu zasygnalizuję jedynie kwestię stosunku człowieka do różnych wymiarów czasu, czyli przeszłości, teraźniejszości i przyszłości. Ô stosunek zwie się za Eukaszewskim ${ }^{5}$ odpowiednio orientacją temporalną: retrospektywną, prezentystyczną i prospektywną. Interesują nas jedynie tzw. czyste orientacje temporalne, czyli takie sytuacje, w których osoba wyraźnie bardziej ceni (preferuje) jeden wymiar czasowy, ale pozostałych nie lekceważy.

Osoby o orientacji retrospektywnej powracają często do przeszłości, którą idealizują. W niewielkim tylko stopniu interesują się teraźniejszością i mają tendencję do wycofywania się z aktywności oraz przejawiają zachowania konserwatywne.

J ednostki o orientacji prezentystycznej, tj. żyjący głównie teraźniejszością, nie mają trudności z adaptacją, wykorzystaniem życia do własnych przyjemności oraz korzyści. Z hedonizmem i koniunkturalizmem łączy się u nich brak refleksji zarówno nad przeszłością jak i przyszłością. Nie prowokują oni ani nie hamują zmian, lecz przede wszystkim wybierają z nich to, co korzystne.

Ludzie żyjący przyszłością (orientacja prospektywna) dość często negują pozostałe wymiary czasu. Nie akceptując teraźniejszości, pragną tworzyć coś nowego co jednak w wielu przypadkach kończy się jedynie na marzycielstwie lub biernym oczekiwaniu na to, co przyniesie bieg zdarzeń. Przyszłość może być rozumiana dwojako: $1^{\circ}$ jako miejsce lokalizacji marzeń, $2^{\circ}$ przedmiot aktywnych zabiegów. Precyzując opis nastawień ku przyszłości mówi się, że orientacja taka może mieć charakter lękowy lub dążeniowy. W pierwszym przypadku przyszłość jest spostrzegana jako zagrożenie a wiele działań jest motywowanych chęcią uniknięcia tych zagrożen. Natomiast drugi typ nastawienia na przyszłość charakteryzuje się nadzieją i oczekiwaniem ${ }^{6}$.

Badając postawę człowieka wobec śmierci, niekiedy zwraca się uwagę na zagadnienie czasu mówiąc o wieku biologicznym oraz tzw. subiektywnym przeżywaniu go ${ }^{7}$. Niektórzy tanatologowie uważają, że człowieka od zwierząt wyróżnia to, iż potrafi nazwać zarówno czas jak i własną

${ }^{5}$ W. Eukaszewski, Szanse rozwoju osobowości, Warszawa 1984, 178-184.

${ }^{6}$ Por. R. Nawrat, Orientacja temporalna. Przeglad technik pomiaru $i$ wyników badań, „Przegląd Psychologiczny” 24 (181), 114-115; D. R e ynolds, R. $\mathrm{K}$ alish, Anticipation of futurity as a function of ethnicity and age, „Journal of Gerentology" 29 (1974), 224-231.

${ }^{7} \mathrm{~J}$. L. Walker, Time estimation and total subjective time, „Perceptual and Motor Skills" 44 (1977), 527-532; L. O. B a s cue, R. E. L a w rence, A study of subjective time and death anxiety in the elderly, „Omega” 1 (1977), 81-90; R. Le mlich, Subjective acceleration of time with aging, „Perceptual and Motor Skills" 41 (1975), 235-238; G. R. Elkins, A. F. Fee, Relationship of physical anxiety to death anxiety and age, ,Journal of Genetic Psychology" 137 (1980), 147-148; P. M. Keith, Perceptions of time remaining and distance from death, „Omega" 12 (1981-82), 307-318. 
śmierć ${ }^{8}$. Inni zaś starają się dowodzić, że gdyby człowiek nie doświadczał upływu czasu, nigdy nie zgłębiałby problemu śmierci ${ }^{9}$. Wynika $\mathrm{z}$ tego, że w osobistym doświadczeniu człowieka łączy się w jakiś sposób przeżywanie stosunku do czasu z odniesieniem do śmierci. Trudno wszakże apriorycznie określić zakres i intensywność owych powiązań i stąd potrzeba badań empirýcznych.

\section{Badania własne}

Zasadniczym problemem, jaki próbuję rozstrzygnąć w tym artykule, jest pytanie: $\mathrm{w}$ jakim stopniu orientacja temporalna wiąże się ze stosunkiem człowieka do śmierci? Do rozstrzygnięcia tak sformułowanego problemu dobrano odpowiednie metody. Przy pomocy kilku twierdzeń skalowych, a także pytania kwestionariuszowego: „Żyję przede wszystkim: a) przeszłością b) teraźniejszością c) przyszłością", wyodrębnione zostały trzy grupy osób różniące się stosunkiem do czasu. Natomiast w oparciu o dane Inwentarza Postaw wobec Smierci opisano postawy wobec śmierci trzech wcześniej wyodrębnionych grup respondentów. Ze względu na to, że w dalszej części artykułu odwoływać się będę do wymiarów postawy wobec śmierci, poniżej przedstawię ich charakterystykę.

Skala postaw wobec śmierci ${ }^{10}$ pozwala opisywać stosunek do zjawiska i problemu śmierci w oparciu o 8 jej wymiarów. Wymiary te są następujące: Centralność, czyli psychiczna bliskość problemu śmierci; Konieczność, tj. dostrzeganie, że śmierć jest immanentną częścią życia; Tajemniczość, tzn. spostrzeganie śmierci jako nieodgadnionej rzeczywistości; Wartość, śmierć bowiem może również prowokować człowieka do pozytywnych rozstrzygnięć; Groza, czyli wywoływanie niepokoju i strachu w człowieku, który umiera bądź obserwuje zjawisko śmierci; Tragiczność, tj. percypowanie śmierci jako wstrząsającego zjawiska; Destrukcyjność, bowiem śmierć powoduje zniszczenie życiowych planów człowieka; Absurdalność, tj. unaocznianie bezsensowności ludzkiego życia.

Zanim przejdziemy do analizy wyników związanych z postawą wobec śmierci grup o różnej orientacji temporalnej, przedstawmy niektóre dane dotyczące respondentów tworzących te grupy.

8 Por. H. Feifel, Judgement of time in younger and older persons, „Journal of Gerontology" 12 (1967), 71-74.

${ }^{9} \mathrm{~Np} . \mathrm{K}$. R. E is s ler, The psychologist and the dying patient, N. York 1955; R. Spitz, Bridges, on anticipation, duration and meaning, ,Journal of the American Psychoanalytic Association" 20 (1972), 721-735.

10 J. Makselon, Skala postawy wobec smierci, „Summarium” 9 (1980), $253-260$. 
Tabela 1. Dane biograficzne respondentów $(\mathrm{N}=225)$

\begin{tabular}{|c|c|c|c|c|c|c|c|c|c|}
\hline & \multicolumn{2}{|c|}{ PEEC } & \multicolumn{2}{c|}{$\begin{array}{c}\text { STAN } \\
\text { CYWILNY }\end{array}$} & \multicolumn{3}{|c|}{ POCHODZENIE } & \multicolumn{2}{c|}{$\begin{array}{c}\text { WYKSZTAE- } \\
\text { CENIE }\end{array}$} \\
\cline { 2 - 8 } & $\mathrm{K}$ & $\mathrm{M}$ & Wolny & Żonaty & $\begin{array}{c}\text { Inteli- } \\
\text { genckie }\end{array}$ & Robotnicze & $\begin{array}{c}\text { Chłop- } \\
\text { skie }\end{array}$ & Srednie & Wyższe \\
\hline $\mathrm{L}$ & 120 & 105 & 164 & 61 & 102 & 89 & 34 & 106 & 119 \\
\hline$\%$ & 53,3 & 46,7 & 72,9 & 27,1 & 45,3 & 39,6 & 15,1 & 47,1 & 52,9 \\
\hline
\end{tabular}

W powyższej tabeli odczytujemy względnie proporcjonalne dane dotyczące płci i wykształcenia. Natomiast zdecydowanie więcej jest osób stanu wolnego $(72,9 \%)$ w porównaniu do żonatych-zamężnych $(27,1 \%)$, oraz pochodzenia inteligenckiego $\mathrm{w}$ porównaniu $\mathrm{z}$ respondentami wywodzącymi się ze wsi (odpowiednio: 45,3 i 15,1\%).

Nieproporcjonalny był również odsetek osób tworzących 3 grupy badanych, a więc tych, którzy preferowali przeszłość, teraźniejszość lub przyszłość. Zestawia to kolejna tabela.

Tabela 2. Preferencja 3 wymiarów czasu oraz średnia (M) i odchylenie standardowe (SD) wieku respondentów

\begin{tabular}{|l|r|r|r|r|}
\hline \multirow{2}{*}{ PREFERENCJA } & L & \multirow{2}{*}{ SD } & \multicolumn{2}{|c|}{ WIEK } \\
\hline przeszłości & & & M & 3,60 \\
teraźniejszości & 13 & 5,8 & 25,3 & 3,88 \\
przyszłości & 123 & 54,7 & 25,4 & 3,10 \\
\hline
\end{tabular}

Jak widać w tab. 2, największy odsetek stanowią osoby żyjące teraźniejszością $(54,7 \%)$. Jest to m.in. uwarunkowane wiekiem badanych, najmłodsi bowiem mieli 22 lata a najstarsi 35, zaś ogólna średnia wieku $\mathrm{M}=25,2$. Nie bez znaczenia jest również i to, że niezwykle mały procent respondentów $(5,8)$ koncentruje się na przeszłości.

Podsumowując powiemy, że prezentowani respondenci to ludzie młodzi, w większości żonaci i pochodzący głównie $\mathrm{z}$ rodzin inteligenckich oraz robotniczych, mało zainteresowani przeszłością a nade wszystko ceniący teraźniejszość. W dalszej części artykułu interesować nas będzie ich stosunek do śmierci.

$\mathrm{Na}$ bazie różnych danych statystycznych opiszę niżej orientację tempo- 
ralną badanych i jej znaczenie w formowaniu się postawy tanatycznej ${ }^{11}$. Najpierw jednak kilka danych nt. częstotliwości myślenia o śmierci.

Tabela 3. Częstatliwość myślenia o śmierci $(\%)$

\begin{tabular}{|c|c|c|c|c|}
\hline \multirow{2}{*}{$\begin{array}{l}\text { O SMIERCI } \\
\text { MYSLE }\end{array}$} & \multicolumn{3}{|c|}{ Orientacja temporalna } & \multirow{2}{*}{ OGOEEM } \\
\hline & przeszłość & teraźniejszość & przyszłość & \\
\hline $\begin{array}{l}\text { bardzo często } \\
\text { często } \\
\text { rzadko } \\
\text { nigdy }\end{array}$ & $\begin{array}{r}6,7 \\
53,3 \\
40,0 \\
-\end{array}$ & $\begin{array}{l}- \\
20,0 \\
53,3 \\
26,7\end{array}$ & $\begin{array}{r}5,3 \\
38,2 \\
53,9 \\
2,6\end{array}$ & $\begin{array}{r}4,7 \\
37,8 \\
51,9 \\
5,6\end{array}$ \\
\hline
\end{tabular}

Ogólnie rzecz biorąc, ponad połowa respondentów $(51,9 \%)$ o śmierci myśli rzadko. Szczegółowa analiza ujawnia zaś istotne zróżnicowania międzygrupowe, wśród żyjących przeszłością bowiem nie ma takich, którzy nie myśleliby o śmierci, podczas gdy u żyjących teraźniejszością jest ich aż $26,7 \%$ a nie ma respondentów, którzy myśleliby o śmierci bardzo często. Często o śmierci myśli jedynie 20\% respondentów tej grupy a wśród żyjących przeszłością - 53,3\%. Stąd między tymi grupami jest statystycznie bardzo istotna różnica $(\mathrm{p}<.001)$. Osoby o orientacji prospektywnej zajmują miejsce pośrednie między stanowiskiem dwóch pozo-

Tabela 4. Srednie (M) i odchylenia standardowe (SD) wymiarów postawy wobec śmierci u osób preferujących przeszłość, teraźniejszość lub przyszłość

\begin{tabular}{|c|c|c|c|c|c|c|}
\hline \multirow{3}{*}{$\begin{array}{l}\text { WYMIARY } \\
\text { SMIERCI }\end{array}$} & \multicolumn{6}{|c|}{ Preferowany } \\
\hline & \multicolumn{2}{|c|}{ przeszłość } & \multicolumn{2}{|c|}{ teraźniejszość } & \multicolumn{2}{|c|}{ przyszłość } \\
\hline & MI & $\mathrm{SD}$ & $\mathrm{lM}$ & $\mathrm{SD}$ & $\mathrm{M}$ & $\mathrm{SD}$ \\
\hline Konieczność (Ko) & 4,827 & 1,64 & 4,323 & 1,07 & 4,792 & 1,27 \\
\hline Centralność (Ce) & 3,513 & 1,00 & 2,816 & 1,08 & 3,056 & 1,26 \\
\hline Tajemniczość (Ta) & 4,821 & 0,91 & 5,136 & 1,30 & 4,640 & 1,44 \\
\hline Wartość (Wa) & 4,449 & 1,26 & 4,350 & 1,18 & 5,017 & 1,10 \\
\hline Groza (Gr) & 4,782 & 1,26 & 4,385 & 1,56 & 4,461 & 1,18 \\
\hline Tragiczność (Tr) & 4,769 & 1,26 & 4,714 & 1,33 & 4,490 & 1,34 \\
\hline Destrukcyjność (De) & 5,231 & 1,55 & 5,035 & 1,31 & 4,637 & 1,28 \\
\hline Absurdalność (Ab) & 4,154 & 1,57 & 4,252 & 1,47 & 3,558 & 1,54 \\
\hline
\end{tabular}

${ }^{11} \mathrm{~W}$ dalszej części artykułu zamiennie używam określeń: „postawa wobec śmierci” i ,postawa tanatyczna” (od thanatos=śmierć), oraz „orientacja temporalna” i ,preferowany wymiar czasu". 
stałych grup. Niemniej jednak różnią się statystycznie istotnie $(p<.05)$ zarówno od żyjących przeszłością jak i zanurzonych w teraźniejszości, choć tym ostatnim są bliżsi aniżeli nastawionym retrospektywnie.

Po opisaniu częstotliwości myślenia o śmierci rozpatrzmy bliżej r ó żnice w poszczególnych wymiarach postawy tanatycznej ze względu na odmienne orientacje temporalne (tab. 4). $\mathrm{Z}$ powyższego zestawienia wynika $\mathrm{m}$.in., że najwyższe wyniki skalowe osiągają poszczególne grupy w odmiennych wymiarach, dla osób bowiem preferujących przeszłość śmierć jest głównie zjawiskiem destrukcyjnym, dla żyjących teraźniejszością - w najwyższym stopniu fenomenem tajemniczym, a preferujący przyszłość podkreślają przede wszystkim wartość śmierci. Być może dzieje się tak dlatego, że żyjący przeszłością mają odczucie utraconego własnego czasu oraz przywołują na pamięć te znane sobie osoby, których śmierć przekreśliła cenione przez innych dokonania. Nie musi to oczywiście dotyczyć wszystkich członków tej grupy, gdyż jest ona w zagadnieniu destrukcyjności śmierci bardzo zróżnicowana, na co wskazuje duża dyspersja wyników $(\mathrm{SD}=1,55)$. Żyjący teraźniejszością nie bardzo chcą ,wikłać się" w problem śmierci (nła co wskazuje najniższy wynik w wymiarze centralności), która jawi się im jako coś nieodgadnionego. Natomiast żyjący przyszłością podkreślają wartość śmierci oraz w najmniejszym stopniu spośród wszystkich analizowanych grup podkreślają destrukcyjny, tragiczny i absurdalny jej charakter. Prawdopodobnie więc orientacja prospektywna i posiadanie w związku z tym określonych planów powoduje bardziej pozytywne wartościowanie śmierci z tego powodu, że albo istotnie wkomponuje się własny zgon $\mathrm{w}$ osobistą historię, która wtedy nie jawi się tak tragicznie i absurdalnie jak u zanurzonych w teraźniejszości, albo - stosując szereg mechanizmów obronnych — „obłaskawia się” śmierć przez przypisywanie jej takiej wartości, jakiej w rzeczywistości się w niej nie widzi.

Zarysowane powyżej niektóre różnice w percepcji poszczególnych wymiarów śmierci staną się jaśniejsze wówczas, kiedy przedstawimy je na wykresie i podamy istotność różnic między średnimi (wykres 1).

Uwzględniając na razie różnice między średnimi wymiarów skali postaw wobec śmierci nie spostrzega się żadnej istotnej różnicy między osobami preferującymi przeszłość lub przyszłość. Istnieje jedynie jedna różnica między respondentami żyjącymi przeszłością i teraźniejszością. Dotyczy ona wymiaru centralności, w którym osoby preferujące teraźniejszość osiągają najniższe wyniki, podczas gdy nastawieni prospektywnie - najwyższe. Trzeba już w tym miejscu zaznaczyć, że nie są to różnice jakościowe, lecz ilościowe, czyli w zakresie intensywności. Również statystycznie istotne różnice pojawiają się między żyjącymi teraźniejszością lub przyszłością i odnoszą się do wymiarów: konieczności, tajemniczości, war- 

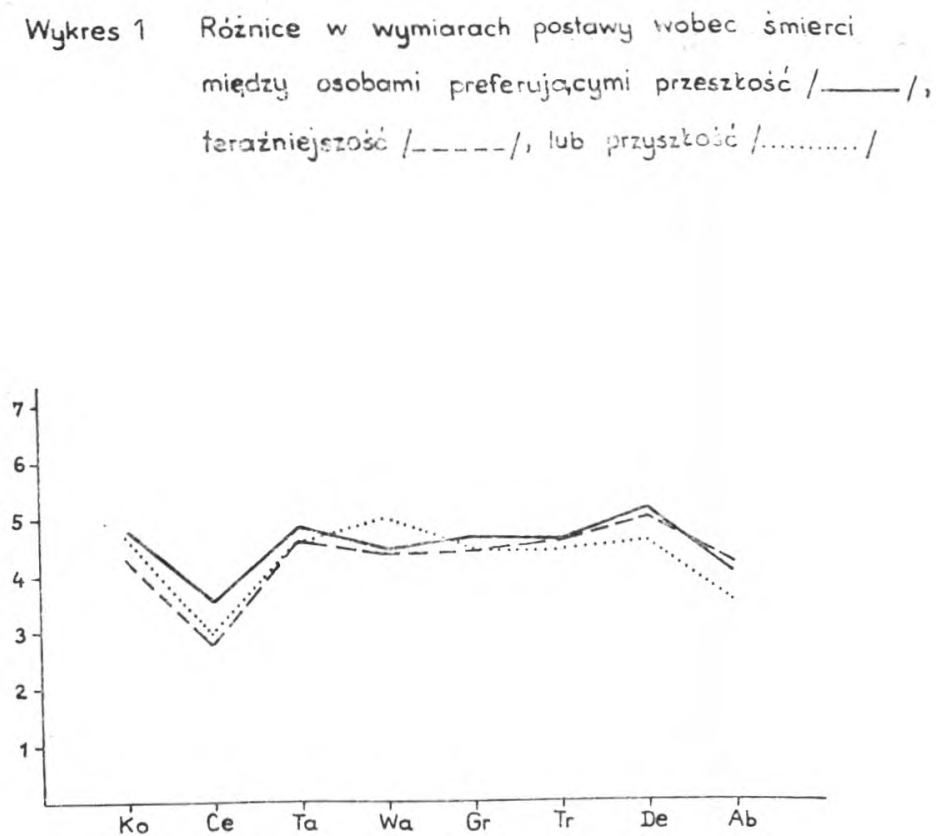

\begin{tabular}{|l|c|c|c|c|c|c|c|c|}
\hline PRZE :TER. & - & .05 & - & - & - & - & - & - \\
\hline PRZE : PRZY & - & - & - & - & - & - & - & - \\
\hline PRZY : TER. & .01 & - & .01 & .001 & - & - & .05 & .001 \\
\hline
\end{tabular}

tości, destrukcyjności i absurdalności, co oznacza, że preferujący teraźniejszość w mniejszym stopniu niż osoby o nastawieniu prospektywnym zauważają tajemniczość i wartość śmierci, natomiast więcej w niej widzą absurdalności i destrukcyjności.

Uzupełnieniem analiz bazujących na teście różnic między średnimi może być prześledzenie powiązań poszczególnych wymiarów śmierci w tych grupach, które najbardziej różnią się między sobą $w$ postawie tanatycznej, czyli w naszym przypadku między osobami preferującymi przyszłość lub teraźniejszość. Prezentuje to tabela 5 .

Biorąc pod uwagę wyniki z tabeli interkorelacji, jak też to, co wiadomo o wiązaniach się wymiarów postawy wobec śmierci u osób o orientacji retrospektywnej, możemy dokonać zestawienia niektórych wymiarów śmierci w zależności od stosunku do czasu. Przedstawia to schemat 1. Zwróćmy uwagę na wiązanie się wymiaru konieczności oraz absurdalności śmierci z innymi jej wymiarami, dostrzegamy bowiem tutaj z jednej strony znaczne korelacje jak i zróżnicowania. I tak np. konieczność śmierci 
Tabela 5. Interkorelacje wymiarów postawy wobec śmierci u osób preferujących przeszłość $(\mathrm{N}=89)$ i teraźniejszośc $(\mathrm{N}=123)$

\begin{tabular}{|c|c|c|c|c|c|c|c|c|}
\hline $\begin{array}{l}\text { WYMIARY } \\
\text { SMIERCI }\end{array}$ & Ko & $\mathrm{Ce}$ & $\mathrm{Ta}$ & Wa & $\mathrm{Gr}$ & $\operatorname{Tr}$ & De & $\mathrm{Ab}$ \\
\hline & \multicolumn{8}{|c|}{ TERAZN I E J Z O SC } \\
\hline Konieczność (Ko) & & $.55^{* * *}$ & .15 & $.27^{* *}$ & $.46^{* * *}$ & $.27^{*}$ & -.01 & .09 \\
\hline Centralność (Ce) & $.50 * * *$ & & .11 & $.43^{* * *}$ & $.41^{* * *}$ & .13 & -.001 & .09 \\
\hline Tajemniczość (Ta) & .07 & -.004 & & -.04 & $.42^{* * *}$ & $.47 * * *$ & $.29^{* *}$ & $.36 * * *$ \\
\hline Wartość (Wa) & $.48^{* * *}$ & $.46^{* * *}$ & -.07 & & .09 & -.14 & -.14 & $-.38 * * *$ \\
\hline Groza (Gr) & $.24^{*}$ & .19 & $.33^{* *}$ & .12 & & $.51^{* * *}$ & $.24 * *$ & $.29 * *$ \\
\hline Tragiczność (Tr) & .10 & .03 & $.32^{* *}$ & -.69 & $.61^{* * *}$ & & $.36^{* *}$ & $.46^{* * *}$ \\
\hline Destrukcyjność(De) & .07 & -.03 & $.30^{* *}$ & -.08 & .14 & $.43^{* * *}$ & & $.55^{* * *}$ \\
\hline \multirow[t]{2}{*}{ Absurdalność (Ab) } & -.13 & $-.29^{* *}$ & $.35^{* * *}$ & $-.33^{* *}$ & $.24^{*}$ & $.40^{* * *}$ & $.44^{* * *}$ & \\
\hline & \multicolumn{8}{|c|}{ PRZYSZもOSC } \\
\hline
\end{tabular}

u osób przeżywających głównie przeszłościowy aspekt czasu wiąże się z jej tajemniczością i tragicznością, natomiast $\mathrm{w}$ pozostałych grupach wymiar konieczności wchodzi w skład określonej triady: u osób zanurzonych w teraźniejszości przeżywanie konieczności śmierci łączy się z jej centralnością w psychice człowieka oraz lękiem wobec niej. Inaczej mówiąc, im wyższa centralność problematyki lub faktu śmierci, tym większa obawa przed nią oraz zrozumienie jej nieuchronności. Istotnie, osoby żyjące teraźniejszością mają najniższy średni wynik w wymiarze konieczności śmierci $\mathrm{w}$ porównaniu $\mathrm{z}$ pozostałymi dwoma grupami, ale też i najniższe wyniki we wspomnianej grozie i centralności ${ }^{12}$.

Osoby o nastawieniu prospektywnym konieczność śmierci wiążą z jej wartością i centralnością, a zatem wartościowanie śmierci przez tę kategorię osób implikuje uwzględnianie nieuchronności śmierci i przynajmniej nieznaczne zaangażowanie $\mathrm{w}$ myślenie o niej.

Wymiar absurdalności śmierci w sposób specyficzny łączy się z pozostałymi czynnikami postawy tanatycznej. Nie dziwi fakt, że między wymiarami absurdalności i wartości śmierci istnieją korelacje ujemne. Bez trudu też można zrozumieć wiązanie się absurdalności z destrukcyjnością, tragicznością oraz tajemniczością śmierci, śmierć bowiem przeżywana jako zjawisko „odsensowniające” życie, na zasadzie generalizacji przeżyć, jest pojmowana jako coś niezrozumiałego, niszczącego i powodującego

12 Triadalne powiązanie wymiarów śmierci jak również możliwości rachunku korelacyjnego nie pozwalają ustalić, który $\mathrm{z}$ owych wymiarów jest przyczynowo ważniejszy, tzn. odpowiedzieć na pytanie, czy np. wzrastająca świadomość śmierci powoduje lęk przed nią i poznanie jej konieczności, czy też odwrotnie - przeżycie grozy śmierci sprawia częstsze o niej myślenie i wyższą akceptację jej nieuchronności. 
Schemat 1. Struktura postawy wobec śmierci

PRZESZLOŚC
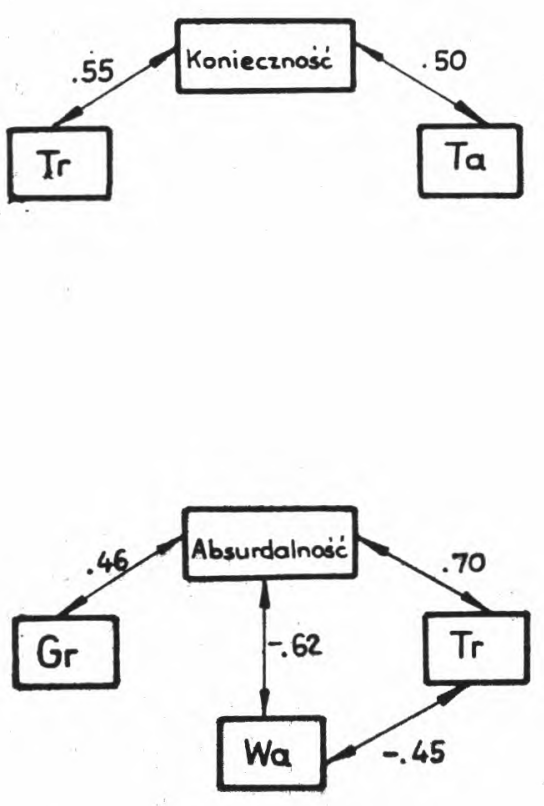

TERAŻNIEJSZOŚŚ
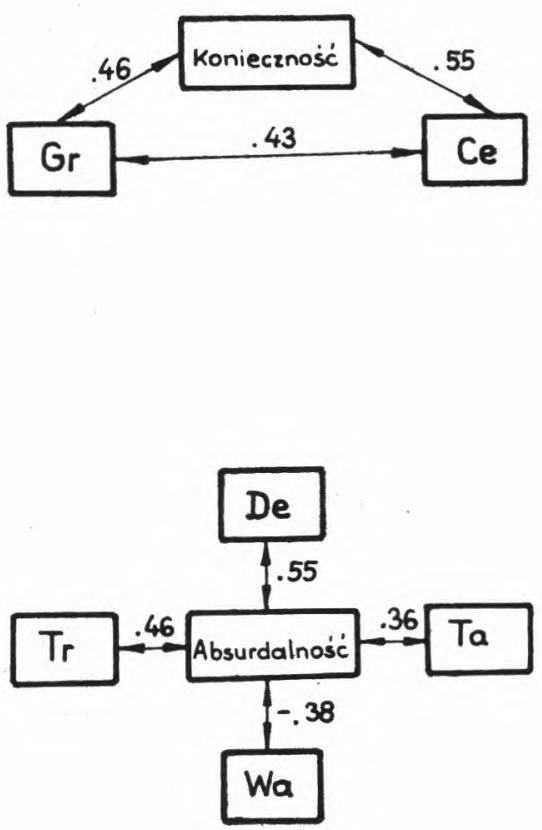

PRZYSZLOŚĆ
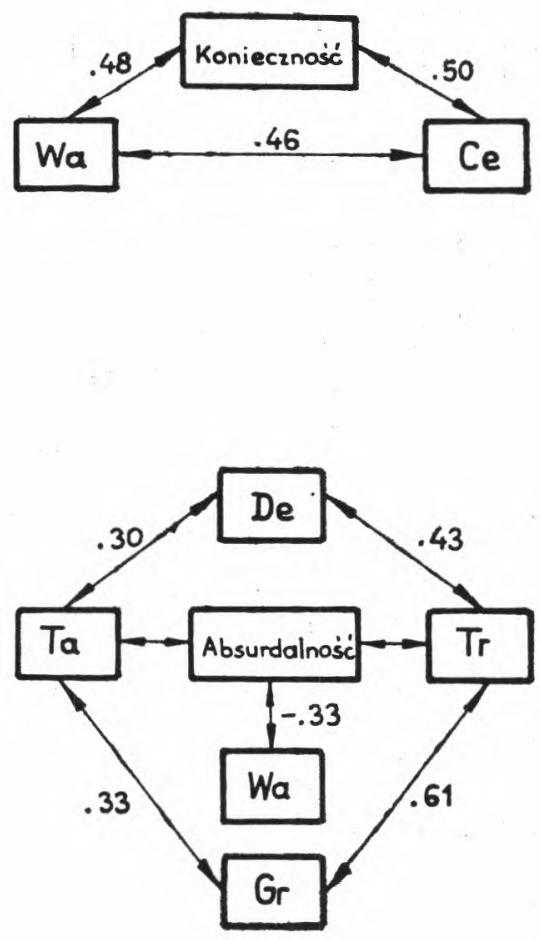
tragiczne przeżycia. U osób nastawionych retrospektywnie trudno wytłumaczyć zauważone ujemne korelacje między wymiarem absurdalności i tragiczności, gdyż oznacza to, że wraz ze wzrostem przeżycia tragiczności śmierci maleje jej tajemniczość i absurdalność. Być może, że intensywniejsza aniżeli w poprzednich grupach tendencja do analizowania dowiadczeń przeszłości prowadzi do wniosku, iż to, co było tragiczne prze-

Tabela 6. Procentowy rozkład głównych odczuć związanych ze śmiercią własną i śmiercią bliskiego u osób o różnej orientacji temponalnej

\begin{tabular}{|c|c|c|c|c|c|c|c|}
\hline \multirow{3}{*}{$\begin{array}{c}\text { ODCZUCIA } \\
\text { ZWIAZZANE } \\
\text { ZE SMIERCIA }\end{array}$} & \multicolumn{6}{|c|}{ Orientacja temporalna } & \multirow[b]{3}{*}{ JGÓEEM } \\
\hline & \multicolumn{2}{|c|}{ przeszłość } & \multicolumn{2}{|c|}{ teraźniejszość } & \multicolumn{2}{|c|}{ przyszłość } & \\
\hline & 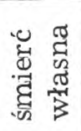 & 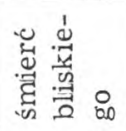 & 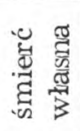 & 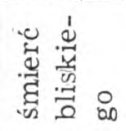 & 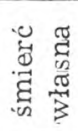 & 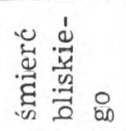 & \\
\hline miechęć do życia & 13,3 & athonat & - & - & - & 1,3 & 1,4 \\
\hline przymijanie & 6,7 & - & 20,0 & 12,5 & 8,4 & 1,3 & 6,5 \\
\hline miepewność przyszłości & - & - & - & - & 10,3 & - & 3,7 \\
\hline rozpacz & - & 26,7 & - & 12,5 & - & 23,1 & 11,1 \\
\hline spokój & 13,4 & - & 26,7 & 12,5 & 10,4 & 3,7 & 8,7 \\
\hline ból & - & 26,7 & - & - & - & 24,4 & 10,6 \\
\hline żal za światem & 13,3 & 6,8 & 13,3 & - & 25,6 & 2,6 & 12,4 \\
\hline nadzieja & 13,4 & 6,8 & 6,6 & 6,3 & 15,4 & 1,3 & 8,3 \\
\hline smutek & 6,7 & 33,0 & 13,4 & 56,2 & 10,4 & 41,0 & 26,2 \\
\hline strach i lęk & 33,2 & - & 20,0 & - & 19,5 & 1,3 & 11,1 \\
\hline
\end{tabular}

stało być tajemnicą i absurdem. Absurdalność śmierci u osób żyjących prospektywnie pojawia się jakby w tle jej destrukcyjności, grozy, tragiczności i tajemniczości, przy czym tylko z dwoma ostatnimi wymiarami łączy się bezpośrednio.

Podejmiemy obecnie problem konsekwencji spotkania się ze śmiercią wyróżniając perspektywę śmierci własnej oraz śmierć bliskiego człowieka. Będzie to w jakimś zakresie analiza behawioralnego składnika postawy tanatycznej. Rozpocznijmy od prezentacji odczuć związanych ze śmiercią (zob. zestawienie w tabeli 6).

W przebadanej próbce dominuje - ogólnie rzecz biorąc - smutek jako reakcja na fakt lub problem śmierci. Najmniej zaznacza się wtedy odczucie niechęci życia, co można tłumaczyć znacznym dynamizmem życiowym młodych ludzi, którzy wprawdzie zniechęcają się do życia, ale nie tyle pod wpływem przeżycia śmierci (ta jako osobisty problem jest dla nich ciągle jeszcze odległa), lecz bardziej w wyniku załamania się sensu życia. Młody mężczyzna (22 lata) przeżywający frustrację egzystencjalną, tak pisze na temat własnych pragnień, osiągnięć i celów: „Więcej niż 
czegokolwiek w życiu pragnąłem śmierci ... najbardziej beznadziejną rzeczą jest brak śmierci ... choroba i cierpienie są darowaniem śmierci". Ów kompleks śmierci przejawia się u tego człowieka także w trudności określenia swego stanowiska względem czasu. Pytany o to, jaki wymiar czasu jest dla niego najistotniejszy, odpowiada lapidarnie: „nie żyję”. Powróćmy jednak do różnic uczuciowych doznań wiążących się ze śmiercią własną lub bliźniego.

Osoby nastawione retrospektywnie myśląc o własnej śmierci doznają lęku, natomiast przeżywając śmierć bliskich mówią o smutku, rozpaczy i bólu (tych dwóch odczuć w ogóle nie ma przy myśleniu o własnej śmierci).

Osoby zanurzone w teraźniejszości, rozważając możliwość własnej śmierci, podkreślają uczucie spokoju (26,7\%) a także, w równej mierze, lęk i przemijanie (20\%). Jest rzeczą charakterystyczną, że bardzo podkreślają (56,2\%) smutek, kiedy przeżywają śmierć bliskich sobie osób.

Respondenci o prospektywnej orientacji czasowej akcentują żal za światem (25,6\%, kiedy myślą o własnej śmierci. Jest to o tyle psychologicznie uzasadnione, że właśnie ta grupa w porównaniu z pozostałymi najlepiej rozumie, że przyszłość zamyka się śmiercią. Stąd właśnie żal za światem. Myśleniu o śmierci bliskich osobom o nastawieniu prospektywnym towarzyszy przede wszystkim smutek (41\%), a w dalszej kolejności — ból i rozpacz (odpowiednio: 24,4 i 23,1\%).

Podsumowując powiemy, że stosunek do czasu w pewnej mierze modyfikuje przeżycia emocjonalne związane ze śmiercią człowieka. Dotyczy to zwłaszcza emocji powodowanych śmiercią bliskiego człowieka, tj. smutku, bólu, rozpaczy. Prawie nieobecne jest wtedy odczucie strachu i lęku, które jednak występuje wyraźnie w czasie myślenia o własnej śmierci. Nie ma téz wtedy odczuć: bólu, rozpaczy, a niechęć do życia występuje jedynie u żyjących przeszłością (13,3\%), natomiast niepewność przyszłości pojawia się u żyjących przyszłością (10,3\%).

Nawiązując do analizy emocjonalnych przeżyć związanych ze śmiercią człowieka, zapytajmy o typ śmierci, którego respondenci najbardziej się obawiają. Przedstawia to tabela 7 .

Tabela 7. Stosunek do czasu a obawa przed śmiercią $(\%)$

\begin{tabular}{|c|c|c|c|c|}
\hline \multirow{2}{*}{$\begin{array}{c}\text { OBAWIAM SIE } \\
\text { SMIERCI }\end{array}$} & \multicolumn{3}{|c|}{ Preferowany czas } & OGOEEM \\
\cline { 2 - 5 } & przeszłość & teraźniejszość & przyszłość & \\
\hline $\begin{array}{c}\text { Nagłej (bez możliwości } \\
\text { przygotowania się) }\end{array}$ & 57,2 & 53,3 & 59,5 & 58,2 \\
$\begin{array}{c}\text { Powolnej (poprzedzonej } \\
\text { cierpieniem) }\end{array}$ & 42,8 & 46,7 & 40,5 & 41,8 \\
\hline
\end{tabular}


Ogólnie, respondenci najbardziej boją się śmierci nagłej, czyli takiej, która nie jest poprzedzona możliwością przygotowania się $(58,2 \%)$, w mniejszym zaś stopniu $(41,8 \%)$ lękają się powolnego umierania poprzedzonego cierpieniem. Nie widać również istotnego wpływu orientacji temporalnej w tym względzie. Szukając uzasadnienia takiego stanu rzeczy, tj. większej obawy przed śmiercią nagłą, można wskazać przynajmniej na dwa źródła: $1^{\circ}$ - obawa przed nagłą śmiercią jest związana $\mathrm{z}$ wiekiem, wydaje się bowiem, że im człowiek starszy, tym bardziej wzrasta obawa przed cierpieniem umierania. Względnie jeszcze młodzi respondenci nie doświadczyli prawdopodobnie krańcowych form oierpienia wiążącego się ze zbliżaniem się ku śmierci i stąd psychologicznie jest to dla nich bardziej odległe aniżeli fakt czy problem śmierci nagłej; $2^{\circ}-\mathrm{w}$ przekonaniu społecznym, budowanym m.in. przez religijne wierzenia, zwraca się uwagę na zło śmierci nagłej, która uniemożliwia należyte, tj. sakramentalne, przygotowanie się. Spiewa się wszakże w Suplikacjach: „Od nagłej a niespodziewanej śmierci, zachowaj nas Panie". Ten społecznie i religijnie usankcjonowany model śmierci złej mógł również w jakimś stopniu oddziaływać na respondentów.

Według powszechnego przekonania fakt i problem śmierci jest czymś prowokującym, ponieważ budzi określonego typu pytania jak też może zmieniać stosunek człowieka do życia. Prześledzimy te zagadnienia odwołując się poniżej do danych liczbowych uzyskanych przez osoby preferujące odmienne aspekty czasowe.

Tabela 8. Rodzaj pytań stawianych podczas refleksji nad śmiercią w zależności od orientacji temporalnej oraz istotność różnic

\begin{tabular}{|c|c|c|c|c|c|c|c|}
\hline \multirow{3}{*}{$\begin{array}{c}\text { RODZAJ } \\
\text { STAWIANYCH PYTAN }\end{array}$} & \multicolumn{6}{|c|}{ Orientacja temporalna } & \multirow{3}{*}{$\begin{array}{l}\text { OGO- } \\
\text { ŁEM }\end{array}$} \\
\hline & \multicolumn{2}{|c|}{ przeszłość } & \multicolumn{2}{|c|}{ teraźniejszość } & \multicolumn{2}{|c|}{ przyszłość } & \\
\hline & 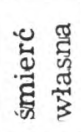 & 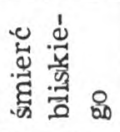 & 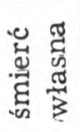 & 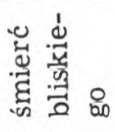 & 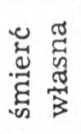 & 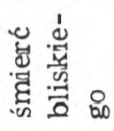 & \\
\hline $\begin{array}{l}\text { Jaki jest początek i cel } \\
\text { życia? }\end{array}$ & 40,0 & 33,3 & 37.5 & 400 & 390 & 427 & 39.9 \\
\hline Jak lepiej żyć? & 26,7 & 33,4 & 6,3 & 20,0 & 45,5 & 45,3 & 38,5 \\
\hline Brak pytań & 33,3 & $3.3,3$ & 56,2 & 40,0 & 15,5 & 12,0 & 21,6 \\
\hline
\end{tabular}

Analiza tabeli 8 nasuwa szereg spostrzeżeń, tym bardziej, że widoczny jest wyraźny wpływ orientacji temporalnej na rodzaj stawianych pytań pod wpływem refleksji o śmierci. Swiadczą o tym statystycznie istotne różnice. Zauważmy najpierw, że respondenci żyjący teraźniejszością, reflektując o własnej śmierci, w najmniejszym stopniu są motywowani 


\begin{tabular}{|l|c|c|}
\hline \multicolumn{1}{|c|}{$\begin{array}{l}\text { POROWNYWANE } \\
\text { ORIENTACJE } \\
\text { TEMPORALNE }\end{array}$} & $\begin{array}{c}|c| \\
\text { smierć } \\
\text { własna }\end{array}$ & $\begin{array}{c}\text { śmierć } \\
\text { bliskiego }\end{array}$ \\
\hline $\begin{array}{l}\text { Przeszłość } \\
\text { Przyszłość }\end{array}$ & .01 & .01 \\
\hline $\begin{array}{l}\text { Przyszłość } \\
\text { Teraźniejszość }\end{array}$ & .001 & .001 \\
\hline $\begin{array}{l}\text { Teraźniejszość } \\
\text { Przeszłość }\end{array}$ & .001 & \\
\hline
\end{tabular}

do myślenia filozoficznego, ponad połowa $(56,2 \%)$ bowiem nie stawia jakichkolwiek pytań. Znamienne jest również i to, że w tej grupie jedynie $6,3 \%$ respondentów pyta o to, jak lepiej żyć. Natomiast pytanie to jest najczęściej stawiane przez osoby żyjące głównie przyszłością, i to zarówno gdy myślą o własnej jak i cudzej śmierci (odpowiednio: 45,5\% i 45,3\%). Wśród prospektywnie nastawionych zauważa się także najmniejszy odsetek tych, którzy pod wpływem refleksji o własnej czy cudzej śmierci nie stawialiby określonych pytań. Ogólnie trzeba powiedzieć, że najbardziej prowokująco ( $w$ sensie stawiania określonych kwestii) oddziałuje śmierć na osoby preferujące przyszłość a najmniej u zainteresowanych głównie teraźniejszością. U tych pierwszych próba ustosunkowania się do zagadnień filozoficznych i etycznych wynika prawdopodobnie $\mathrm{z}$ potrzeby intelektualno-egzystencjalnego opanowania przestrzeni przyszłości, u drugich natomiast nie pojawia się z taką ostrością pytanie ,jak lepiej żyć?", ponieważ istotne dla nich jest to, co istnieje, a nie to, co może być. Ich zdaniem, istnieje świat, a więc co najwyżej trzeba pytać o jego początek i cel; nie ma natomiast potrzeby zastanawiania się nad tym, jak go polepszać.

Jak już zaznaczyłem, refleksja o śmierci może zmieniać stosunek do życia, gdyż życie i śmierć to zjawiska korelatywne. Najogólniej mówiąc, pod wpływem przeżycia problemu lub faktu śmierci z mi enia się styl życia na eksploatatorski, w którym chodzi o wykorzystanie wszystkiego do końca a także o użycie świata, lub na autokorekcyjny, gdy wyraźna jest potrzeba poprawy siebie. Jest oczywiste, że spotkanie śmierci niekiedy również nie ma żadnego znaczenia w modyfikowaniu lub radykalnym przekształcaniu stylu życia. A jak przedstawia się to zagadnienie w przebadanej próbce? Obrazuje to tabela 9. 
Tabela 9. Procentowy rozkład danych dotyczących wpływu myślenia o śmierci własnej lub bliskiego na postawę wobec życia u osób prezentujących odmienne orientacje temporalne

\begin{tabular}{|c|c|c|c|c|c|c|c|}
\hline \multirow{3}{*}{$\begin{array}{l}\text { STOSUNEK } \\
\text { DO ŻYCIA }\end{array}$} & \multicolumn{6}{|c|}{ Orientacja temporalna } & \multirow[b]{3}{*}{$\begin{array}{l}\text { OGO- } \\
\text { ŁEM }\end{array}$} \\
\hline & \multicolumn{2}{|c|}{ przeszłość } & \multicolumn{2}{|c|}{ teraźniejszość } & \multicolumn{2}{|c|}{ przyszłość } & \\
\hline & 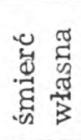 & 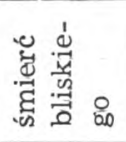 & 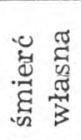 & 岕离离 & 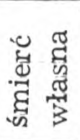 & 思岂 & \\
\hline Eksploatatorski & 13,3 & - & 13,3 & 20,0 & 17,6 & 15,1 & 15,0 \\
\hline Autokorekcyjny & 40,0 & 42,9 & 33,3 & 20,0 & 68,9 & 50,7 & 42,4 \\
\hline Niezmienny & 46,7 & 57,1 & 53,4 & 60,0 & 13,5 & 34,2 & 42,6 \\
\hline
\end{tabular}

Dane tabeli 9 sugerują, że dość wyraźnie różnią się osoby żyjące przyszłością w stosunku do pozostałych dwóch grup $(\mathrm{p}<.01)$. Pod wpływem myślenia o śmierci, zwłaszcza własnej, postanawiają się poprawić (68,9\%), podczas gdy znaczny procent żyjących teraźniejszością nie dokonuje zmian w stylu życia. Generalnie porównując ustosunkowanie się do życia osób preferujących różne wymiary czasu spostrzega się albo chęć poprawy siebie, albo niezmienność stylu życia. W mniejszym zaś stopniu pojawia się chęć wykorzystania życia.

Przedstawione powyżej dane zdają się do pewnego stopnia potwierdzać przekonanie o prowokacyjnym charakterze śmierci, szczególnie u osób o prospektywnej orientacji temporalnej. Jest też jednak faktem, że znaczna część respondentów nie zmienia swego stosunku do życia pod wpływem przeżywania śmierci i jest przy tym charakterystyczne, że większą niezmienność stylu życia we wszystkich grupach widać w przypadku śmierci kogoś bliskiego aniżeli podczas refleksji o własnej śmierci. Powstaje wszakże w związku z tym pytanie, czy ta niezmienność jest całkowita, czyli autentyczna, gdyż jest wielce prawdopodobne, iż działają tutaj silne mechanizmy obronne wypierania i zaprzeczania.

\section{Wnioski końcowe}

Przeprowadzone analizy oddziaływania określonej orientacji temporalnej na postawę wobec śmierci pozwalają wnosić, że:

$1^{\circ}$ - Osoby żyjące przeszłością najczęściej myślą o śmierci i najbardziej podkreślają jej destrukcyjny chanakter. Myśląc o własnej śmierci głównie odczuwają strach i lęk, a przy przeżywaniu śmierci bliskich pojawia się u nich smutek. Pod wpływem 
przeżycia faktu lub problemu śmierci specjalnie interesują się kwestią początku i celu życia.

$2^{\circ}$ - Respondenci zainteresowani przede wszystkim teraźniejszością o śmierci myślą najrzadziej, bowiem zajmuje ona w ich psychice peryferyjną pozycję. Kiedy jednak do takiego myślenia dochodzi, podkreślają tajemniczość zjawiska śmierci. Przeżywając śmierć bliskich sobie osób $\mathrm{w}$ stopniu zdecydowanie wyższym aniżeli pozostałe grupy podkreślają smutek. Reflektując od czasu do czasu nad własną śmiercią przeżywają głównie spokój. Zresztą tego typu refleksja nie budzi u nich zbyt często egzystencjalnie ważkich pytań. Są oni też najmniej podatni na zmianę stylu życia pod wpływem przeżycia śmierci.

$3^{\circ}$ - Jednostki o orientacji prospektywnej w pewnej mierze zajmują pozycję pośrednią między żyjącymi przeszłością lub teraźniejszością. Smierci przypisują pewną wartość i w związku z tym mniejszą absurdalność aniżeli pozostałe grupy. Główną emocją, jaka się pojawia przy refleksji o własnej śmierci, jest żal za światem. Zastanawiając się nad śmiercią, osoby żyjące przyszłością nierzadko pytają o to, jak lepiej żyć.

\section{TIME PERSPECTIVE AND ATTITUDE TOWARD DEATH}

\section{S u m m a r y}

Time is one of the most important dimensions of the human existence. In this article problem of the relation between time perspective (time-orientation) and attitude toward death is examined. 242 subjects, aged $21-35$ years $(\mathrm{M}=25.3)$, were tested and three groups were distinguished: wtih past, present, and future time perspective. Their attitudes toward death are different, e.g. persons who prefer present time orientation perceive death as a most mysterious phenomenon, living in present time perspective stress destructiveness of death, and for respondents with the future time orientation death presents special value.

Psychological aspects of the statistical signifficant differences between three groups in eight dimensions of death attitude are discusised. In further thanatopsychological studies correlation between personality, attitudes toward death (especially death anxiety) and time perspective should be analyzed. 